УДК 338.43 : 664

DOI: https://doi.org/10.32782/2415-8801/2020-3.25

Бутнік-Сіверський О.Б. доктор економічних наук, професор, завідуючий кафедри економіки, обліку та фінансів, Інститут післядипломної освіти Національного університету харчових технологій Міністерства освіти і науки Украӥни

Коткова Н.С. кандидат економічних наук, старший науковий співробітник, стариий науковий співробітник відділу економічних досліджень та інноваційного провайдингу, Інститут продовольчих ресурсів Національної академії аграрних наук Украӥни

\author{
ЕКОНОМЕТРИЧНА ОЦІНКА РЕЗУЛЬТАТИВНОСТІ \\ ІННОВАЦІЙНО-ІНВЕСТИЦЙНОГО ПОТЕНЦІАЛУ \\ В ХАРЧОВІЙ ПРОМИСЛОВОСТІ УКРАЇНИ
}

\begin{abstract}
У статті здійснено економетричну оцінку результативності інноваційно-інвестиційного потенціалу в харчовій промисловості Украӥни. Із цією метою для більш адекватного відображсення реальних взасмовідносин в економічних процесах застосовано систему регресійних рівнянь. При цьому для якості оцінки параметрів регресійних моделей використано низку показників, що характеризують ступінь відхилення від фактичних даних, а також значимість змінних, до яких віднесено розрахунки коеріцієнтів детермінації й обчислення середньої помилки апроксимації. Про результативність свідчть оцінка впливу капітальних інвестицій на одного зайнятого та фондоозбросності праці на продуктивність праці в харчовій промисловості, яка має високий рівень коефіцієнта детермінації, що свідчить про залежність продуктивності праці від досліджуваних факторів. Ключовим напрямом підвищення ефективності харчової промисловості є збільщення інвестицій у галузі, у тому числі й іноземних, та зростання рівня фондоозбросності, а також більш активного залучення провідних світових транснаціональних корпорацій до роботи на внутрішньому ринку Украӥни.
\end{abstract}

Ключові слова: інноваційно-інвестиційний потенціал, економетрична оцінка результативності, прямі іноземні інвестииії, продуктивність праціі, капітальні інвестиџії на одного праџюючого, фондоозброєність.

\title{
ECONOMETRIC EVALUATION OF EFFICIENCY OF INNOVATION AND INVESTMENT POTENTIAL IN THE FOOD INDUSTRY OF UKRAINE
}

\author{
Butnik-Siversky Oleksandr \\ Institute of Postgraduate Education \\ National University of Food Technologies of the Ministry of Education and Sciences of Ukraine
}

Kotkova Natalya

Food Resources Institute

National Academy of Agrarian Sciences of Ukraine

The article provides an econometric assessment of the effectiveness of innovation and investment potential in the food industry of Ukraine. To this end, a system of regression equations is used to more adequately reflect the real relationships in economic processes. A number of indicators characterizing the degree of deviation from the actual data, as well as the significance of variables, which include calculations of coefficients of determination and calculation of the average error of approximation, were used for the quality of estimation of parameters of regression models. Accelerating the growth of labor productivity in all sectors of the economy is an objective necessity, as this growth is the most important prerequisite for further raising the material and cultural standard of living of the people in our country. The precondition for the growth of labor productivity is, first of all, scientific and technical progress, the introduction of resource-saving technologies, the improvement of production technology and products. The formation and effective use of innovation and investment potential of industry is the basis for sustainable development of the food industry economy and increase its competitiveness. The effectiveness is evidenced by the assessment of the impact of capital investment per employee and capital adequacy on labor productivity in the food industry, which has a high level of coefficient of determination, which indicates the dependence of labor productivity on the studied factors. It should be noted that labor productivity is directly dependent on the amount of investment and efficiency of existing means of production. However, it should be noted that the nature of the relationship between capital investment and productivity is ambiguous. The key direction of increasing the efficiency of the food industry is to increase investment in the industry, including foreign and increase the level of capital, as well as more active involvement of the world's leading multinational corporations to work in the domestic market of Ukraine. This will help increase labor productivity, as foreign companies invest more capital per unit of labor, which is directly related to its increase.

Keywords: innovation and investment potential, econometric performance appraisal, foreign direct investment, labor productivity, capital investment per employee, capital adequacy. 
Постановка проблеми. Формування та ефективне використання інноваційного та інвестиційного потенціалу промисловості є основою сталого розвитку економіки харчової промисловості й підвищення її конкурентоспроможності. Проблеми визначення ефективності інноваційно-інвестиційного потенціалу $\epsilon$ вкрай актуальними для галузей харчової промисловості України. Вирішення цих проблем і формування працездатної системи показників дають змогу оцінити результативність поточного функціонування інноваційної системи галузі та ступінь реалізації поставлених перед нею завдань і цілей інноваційного розвитку.

Загалом, оцінюючи ефективність та результативність інноваційно-інвестиційного потенціалу та економічної діяльності, частіше розглядають такі підходи до іiї визначення:

- визначення результативності, ефективності та оптимальності економічної діяльності (немає ще єдності як у виборі показників оцінки, так і методичних підходів до їх використання) [12];

- визначення ефективності різних видів економічної діяльності (операційної, інвестиційної, інноваційної, фінансової);

- визначення ефективності інноваційно-інвестиційного потенціалу та економічної діяльності окремих суб'єктів, стадій або етапів економічної діяльності.

Суттєве значення щодо результативності має становлення інноваційно-інвестиційного потенціалу, який являє собою певним чином упорядковану сукупність інноваційних та інвестиційних ресурсів, ефективне використання яких сприяє підвищенню національної конкурентоспроможності на світовому ринку та сталого розвитку господарської системи.

Під результативністю будемо розуміти використання інноваційно-інвестиційного потенціалу підприємств, обсяг їхньої продукції і темпи його зростання, частку виробництва інноваційної продукції в загальному обсязі виробництва та іiі динаміку, обсяг отриманого прибутку і створеної доданої вартості підприємствами галузі, число швидкозростаючих інноваційних фipм (gazellecompanies) та їхню частку в загальному обсязі виробництва. Специфікою оцінки інноваційноінвестиційного розвитку галузі $є$ необхідність ураховувати як ефект обсяг прямих зовнішніх інвестицій у підприємства. Більше того, приплив фінансових ресурсів ззовні продукує синергетичний ефект в економіці та зумовлює кроки до активного залучення провідних світових транснаціональних корпорацій до роботи на внутрішньому ринку України.

Сьогодні науковці прагнуть знайти методи поліпшення якості прийнятих управлінських рішень про напрями потоків інвестицій, що призводить до створення нового інструментарію оцінки результативності інноваційно-інвестиційного потенціалу.

У процесі дослідження інноваційного потенціалу підприємства більшість авторів розглядає фінансовий, виробничо-технологічний, економічний, науково-технічний i кадровий потенціал в ув'язці 3 ресурсним забезпеченням i взаємозв'язком, що 3 позиції інноваційного потенціалу утворюють діалектичну єдність як передумова для подальшого економічного розвитку. Саме інноваційно-інвестиційний потенціал потрібно розглядати не тільки у взаємозалежності від інших компонентів загального потенці- алу підприємства, а й із позицій здатності створювати та комерціалізувати нововведення або окремі інновації різного рівня. Його необхідно досліджувати за стадіями інноваційного процесу конкретного підприємства $з$ погляду можливості задоволення суспільних i особистих потреб через створення нових зразків продукції, технології та ін.

Розглянемо наші застереження на прикладі одного із суттєвих результативних показників, яким є приріст продуктивності праці, що є одним із найважливіших показників ефективності як інноваційної, так і інвестиційної діяльності. Ріст показника продуктивності праці $\epsilon$ важливою умовою розвитку продуктивних сил країни і головним джерелом росту національного доходу, що, відповідно, є передумовою виходу з економічної кризи та становлення пропорційного економічного зросту. Продуктивність є основою підвищення конкурентоспроможності підприємств, реальної заробітної плати працюючих, виступає джерелом для прийняття управлінських рішень щодо підвищення рентабельності, технічного та організаційного реформування виробництва, управління людськими ресурсами, оцінки конкурентоспроможності, визначення цінової політики тощо. Авторська гіпотеза полягає у тому, що ефективність праці безпосередньо залежить не тільки від обсягів вкладень, а й від обсягів фізичного капіталу.

Слід зазначити, що продуктивність праці знаходиться у прямій залежності від обсягу інвестицій та ефективності діючих засобів виробництва. Разом із тим слід звернути увагу на те, що характер взаємозв'язків між капітальними інвестиціями та продуктивністю праці неоднозначний.

Аналіз останніх досліджень і публікацій. Під час оцінки взаємозалежності інвестицій та продуктивності праці більшість авторів досліджує їх 3 якісного боку. До них відносяться О.О. Герасименко [6], С.О. Гуткевич [3], І.В. Заюков [5], А.М. Колот [6], К.М. Парамонова [10], Л.І. Федулова [10], Р.М. Чорна [13] та багато інших. Разом із тим певні аспекти, пов'язані з моделюванням впливу окремих чинників на продуктивність праці в харчовій промисловості України, залишаються недостатньо дослідженими.

Постановка завдання. Метою статті $є$ економетрична оцінка результативності інноваційно-інвестиційного потенціалу для визначення впливу капітальних інвестицій, у тому числі й іноземних, на продуктивність праці та зростання рівня фондоозброєності в галузях харчової промисловості України.

Виклад основного матеріалу дослідження. Харчова промисловість є соціально значущою галуззю. Продукція харчової промисловості України відома за кордоном завдяки м'ясним, молочним і кондитерським брендам, які завоювали споживчі переваги завдяки натуральності, смаковим якостям і конкурентній ціні.

Підтримка агропромислового комплексу, зокрема харчової промисловості, є одним із найбільш пріоритетних і стратегічних напрямів розвитку країни. Забезпечуючи високу конкурентоспроможність підприємствам харчової промисловості, держава підтримує необхідний рівень продовольчої безпеки на внутрішньому ринку, а також має можливість експортувати частину виробленої продукції на зовнішні ринки. Нині відзначається тенденція до збільшення попиту і цін на 
продовольство на світовому ринку, що викликає необхідність створювати сприятливі умови для інноваційного розвитку та збільшення виробничих потужностей вітчизняних підприємств харчової галузі.

Харчова промисловість $є$ однією з найбільш перспективних галузей промисловості, що швидко розвивається. Питома вага в загальному обсязі промисловості України станом на 2018 р. становила 20,74\%, що вище рівня 2012 р. на 2,16 п. п. (табл. 1).

Сьогодні виробники повинні випускати великий асортимент товарів і створювати нові продукти, зважаючи на зростаючі запити споживачів. Щоб вижити на світовому ринку, необхідно розвивати виробництво й скорочувати витрати за рахунок підвищення ефективності бізнесу.

Із наведених даних табл. 1 бачимо, що обсяги реалізованої продукції харчової промисловості України збільшилися в 2018 р. порівняно 32012 р. на 395311,79 млн грн (або в 1,42 рази).

Варто відзначити, що збільшення обсягів реалізованої продукції харчової промисловості України та чистого прибутку на 8353,25 тис грн (або в 1,16 рази) не призвело до збільшення рентабельності операційної діяльності.

Рентабельність операційної діяльності в 2018 р. порівняно 32012 р. зменшилася на 1,5 п. п. і становила 4,9\%.
При цьому кількість підприємств зменшилася на 53 одиниці, а кількість зайнятих працівників - на 93951 тис осіб.

Найважливішою передумовою здійснення економічних перетворень у харчовій промисловості, як і будь-якій сфері народного господарства, є інвестиції, які здатні забезпечити вкладення в розвиток і вдосконалення виробництва, соціальну сферу, кадровий потенціал.

Без інвестицій неможливо реалізувати завдання щодо структурної перебудови галузі, підвищення техніко-економічного рівня конкурентоспроможності вітчизняного виробництва.

Україна сьогодні - країна, відкрита для іноземних інвестицій, що створює сприятливі умови для ефективного ведення бізнесу. Країна займає вигідне економікогеографічне та геополітичне становище, має сприятливі природно-кліматичні умови, створений високий науково-технічний, промисловий і експортний потенціал, є висококваліфіковані та порівняно недорогі трудові ресурси. У табл. 2 представлено основні показники інвестиційного розвитку харчової промисловості України протягом 2012-2018 рр.

Із даних табл. 2 бачимо, що зростання капітальних інвестицій у 2018 р. порівняно $з 2012$ р. становило 16 933,1 млн грн. Але слід зазначити, що питома вага

Основні показники розвитку харчової промисловості України протягом 2012-2018 рр.

\begin{tabular}{|c|c|c|c|c|c|}
\hline \multirow[b]{2}{*}{ Показники } & \multicolumn{3}{|c|}{ Роки } & \multicolumn{2}{|c|}{ Відхилення, +/- } \\
\hline & 2012 & 2017 & 2018 & $\begin{array}{l}2018 \text { p. } \\
\text { від } 2017 \text { р. }\end{array}$ & $\begin{array}{l}2018 \mathrm{p} . \\
\text { від } 2012 \text { р. }\end{array}$ \\
\hline Рентабельність операційної діяльності, \% & 6,4 & 5,1 & 4,9 & $-0,20$ & $-1,50$ \\
\hline Чистий прибуток (збиток), млн грн & 7183,92 & 8896,28 & 15537,17 & 6640,89 & 8353,25 \\
\hline Кількість підприємств, од. & 5768 & 5498 & 5715 & 217,00 & $-53,00$ \\
\hline Обсяг реалізованої продукції, млн грн & 278511,19 & 636536,33 & 673822,98 & 37286,65 & 395311,79 \\
\hline $\begin{array}{l}\text { Питома вага харчової промисловості } \\
\text { в промисловості України, \% }\end{array}$ & 18,58 & 22,59 & 20,74 & $-1,85$ & 2,16 \\
\hline Кількість зайнятих працівників, тис ос. & 416979 & 323613 & 323028 & $-585,00$ & $-93951,00$ \\
\hline Середньомісячна заробітна плата працівників, грн/ос. & 2882,92 & 6633,55 & 8253,31 & 1619,76 & 5370,39 \\
\hline
\end{tabular}

Джерело: розраховано та складено з використанням [4]

Таблиця 2

Основні показники інвестиційного розвитку харчової промисловості України протягом 2012-2018 рр.

\begin{tabular}{|l|c|c|c|c|c|}
\hline \multicolumn{1}{|c|}{ Показники } & \multicolumn{3}{c|}{ Роки } & \multicolumn{2}{c|}{ Відхиленн, +/- } \\
\cline { 2 - 6 } & $\mathbf{2 0 1 2}$ & $\mathbf{2 0 1 7}$ & $\mathbf{2 0 1 8}$ & $\begin{array}{c}\mathbf{2 0 1 8} \mathbf{p .} \\
\text { від 2017 p. }\end{array}$ & $\begin{array}{c}\mathbf{2 0 1 8} \text { р. } \\
\text { від 2012 p. }\end{array}$ \\
\hline Капітальні інвестиції, млн грн & 13279,7 & 18927,6 & 30212,8 & 11285,2 & 16933,1 \\
\hline $\begin{array}{l}\text { Темп приросту капітальних інвестицій, у \% до попере- } \\
\text { днього року }\end{array}$ & 10,10 & $-11,10$ & 59,62 & 70,72 & 49,52 \\
\hline $\begin{array}{l}\text { Питома вага капітальних інвестицій харчової промисло- } \\
\text { вості у переробній промисловості країни, \% }\end{array}$ & 31,41 & 25,62 & 29,95 & 4,33 & $-1,46$ \\
\hline $\begin{array}{l}\text { Питома вага капітальних інвестицій харчової промисло- } \\
\text { вості у промисловості країни, \% }\end{array}$ & 14,50 & 13,21 & 15,11 & 1,9 & 0,61 \\
\hline Прямі інвестиції (акціонерний капітал), млн дол. США & 2194,2 & 2530,5 & 2758,4 & 227,9 & 564,2 \\
\hline $\begin{array}{l}\text { Темп приросту прямих іноземних інвестицій, у \% до } \\
\text { попереднього року }\end{array}$ & 10,99 & 4,61 & 9,01 & 4,4 & $-1,98$ \\
\hline $\begin{array}{l}\text { Питома вага прямих іноземних інвестицій харчової про- } \\
\text { мисловості у переробній промисловості країни, \% }\end{array}$ & 17,70 & 33,63 & 34,48 & 0,85 & 16,78 \\
\hline $\begin{array}{l}\text { Питома вага прямих іноземних інвестицій харчової про- } \\
\text { мисловості у промисловості країни, \% }\end{array}$ & 12,68 & 26,18 & 26,16 & $-0,02$ & 13,48 \\
\hline
\end{tabular}

Джерело: розраховано та складено з використанням [4] 
капітальних інвестицій харчової промисловості у переробній промисловості країни зменшилася 3 31,41\% у 2012 р. до 29,95\% у 2018 р. Це зумовлено тим, що для макроекономічної стабілізації українська влада була змушена скоротити кредитування держпрограм. Таким чином, внутрішні джерела фінансування інвестиційної активності виявилися обмеженими.

Як свідчить аналіз динаміки показників інвестиційного розвитку, харчова промисловість України приваблива для іноземних інвесторів. Аналізуючи динаміку надходження іноземних інвестицій, слід зазначити, що їх розмір у 2018 р. порівняно з 2012 р. у цілому зріс на 564,2 млн грн. Збільшення прямих іноземних інвестицій - найважливіший чинник активізації економічного реформування в харчовій промисловості. Разом із припливом коштів залучаються також нові передові технології, певні інновації у виробництві та управлінні, які підприємства галузі можуть взяти за приклад для впровадження нововведень на своїх підприємствах [8].

3 аналітичного погляду важливу роль відіграє також динаміка питомої ваги прямих іноземних інвестицій харчової промисловості у переробній промисловості країни та промисловості у цілому. Станом на 2018 р. їхня частка становить $34,48 \%$ і $26,16 \%$, тоді як у 2012 р. - 17,7\% і 12,68\% відповідно. Отже, у подальшому необхідно посилювати заходи щодо лібералізації економіки з метою поліпшення ділового та інвестиційного клімату, а також більш активно залучати провідні світові транснаціональні корпорації (ТНК) до роботи на внутрішньому ринку України (у тому числі за рахунок надання податкових та інших пільг). Для сучасної України транснаціоналізація підприємств, зазначає I.O. Пєнська, може виступити економічним механізмом, який визначить нові пріоритети суспільного відтворення, цілі зовнішньоекономічної політики, особливості та умови участі країни в міжнародному поділі праці. Саме ТНК - основний структурний елемент економіки більшості країн, провідна сила їхнього розвитку та підвищення ефективності [11].

На основну увагу заслуговують ТНК, які займаються виробництвом продукції на території України i, як наслідок, розвивають промисловий потенціал країни та створюють нові робочі місця. Сьогодні в Україні, зазначає I.O. Пєнська [11], найбільша кількість ТНК представлена у переробній промисловості. За підсумками 2019 р. більшість із них були прибутковими (табл. 3 ).

Дані щодо вкладання інвестицій за 2013 р. і найбільші транснаціональні інвестори України наведено у табл. 4.

Наведені дані таблиць, наприклад по корпорації McDonald's, свідчать, що індекс обсягу вкладень у 2013 р. на одиницю виручки у 2014 р. по корпорації

Фінансові результати ТНК в Україні за 2014 та 2019 рр.

Таблиця 3

\begin{tabular}{|c|c|c|c|c|c|c|}
\hline \multirow{2}{*}{$\begin{array}{c}\text { № } \\
\text { 3/II }\end{array}$} & \multirow{2}{*}{ Материнська компанія } & \multirow{2}{*}{ Галузь } & \multicolumn{2}{|c|}{ Виручка, млн грн } & \multicolumn{2}{|c|}{ Прибуток, млн грн } \\
\hline & & & 2014 рік & 2019 рік & 2014 рік & 2019 рік \\
\hline 1 & Japan Tobacco (Японія) & Тютюнова & 11706,8 & 20592,1 & 1238,5 & 1115,5 \\
\hline 2 & Philip Morris International (Швейцарія / США) & Тютюнова & 6957,3 & 37604,2 & 746,3 & 2944,2 \\
\hline 3 & Imperial Tobacco (Великобританія) & Тютюнова & 1358,9 & 21070,0 & 520,2 & $-116,7$ \\
\hline 4 & Bunge (США) & Агропромислова & 5319,3 & 23097,6 & 226,7 & $-414,0$ \\
\hline 5 & Cargill (США) & Агропромислова & 14470,9 & 18674,5 & 1646,0 & $-110,6$ \\
\hline 6 & Nestlé (Швейцарія) & Харчова & 5855,3 & 10768,6 & $-1034,1$ & 341,1 \\
\hline 7 & McDonald's (США) & Харчова & 3275,0 & 7827,7 & $-69,9$ & 945,8 \\
\hline 8 & Toyota (Япония) & Машинобудування & 4568,9 & 12876,7 & 578,2 & 834,7 \\
\hline 9 & Procter \& Gamble (США) & Хімічна & 9451,5 & 10878,6 & 603,8 & 456,2 \\
\hline 10 & Coca-Cola HBC (Швейцарія) & Харчова & 2802,9 & 6919,1 & $-303,8$ & 422,8 \\
\hline
\end{tabular}

Джерело: складено з використанням [1]

Найбільші ТНК, які вкладали інвестиції у дочірні компанії, філіали та спільні підприсмства в Україні в 2013 р.

\begin{tabular}{|c|l|l|l|c|}
\hline $\begin{array}{c}\text { № } \\
\text { 3/п }\end{array}$ & \multicolumn{1}{|c|}{ Корпорація } & \multicolumn{1}{|c|}{ Країна } & $\begin{array}{c}\text { Обсяг вкладень, } \\
\text { млн грн }\end{array}$ \\
\hline 1 & McDonald's Corporation & США & Харчова промисловість & 198,3 \\
\hline 2 & Nestlé S.A. & Швейцарія & Харчова промисловість & 178,5 \\
\hline 3 & British American Tobacco & Великобританія & Тютюнова & 166,8 \\
\hline 4 & British Petroleum & Великобританія & Нафтогазова промисловість & 142,6 \\
\hline 5 & Procter \& Gamble & США & Хімічна промисловість & 135,1 \\
\hline 6 & Shell & Нідерланди & Нафтогазова промисловість & 124,9 \\
\hline 7 & Coca-Cola & США & Харчова промисловість & 121,0 \\
\hline 8 & Unilever & $\begin{array}{l}\text { Великобританія } \\
\text { Нідерланди }\end{array}$ & Харчова промисловість та побутова хімія & 115,5 \\
\hline 9 & РepsiCola & США & Харчова промисловість & 112,3 \\
\hline
\end{tabular}

Джерело: складено з використанням [11] 
McDonald's становив 0,0605, i, відповідно, за того ж обсягу вкладень у 2019 р. він становитиме 0,0253 ; різниця між ними 0,0352 свідчить про присутність реальної віддачі вкладень (інвестицій) у зростання виручки у 2019 р., а тим самим і прибутку.

Іноземні транснаціональні корпорації, справедливо зазначає I.O. Пєнська [11], готові здійснювати свою діяльність в Україні, проте на заваді їм стають такі чинники, як: нестабільне й надмірне регулювання, відсутність в Україні сталої стратегії та відповідного національного плану дій, недосконалість національного законодавства, нечітка правова система, нестабільність економічної та політичної ситуації, високий рівень корупції в усіх сферах господарської діяльності та неспроможність судової системи належним чином виконувати свої функції, критична ситуація у сфері незалежності судової системи (123-є місце серед 129 країн світу), низький платоспроможний попит українських споживачів, труднощі у спілкуванні з урядовими та приватизаційними органами, переобтяженість регуляторними нормами та складність податкової системи, суттєве податкове навантаження.

Водночас залучення іноземних інвестицій сприяє підвищенню продуктивності праці, оскільки іноземні компанії вкладають більше капіталу на одиницю праці, що має безпосередній зв'язок з їі підвищенням. Саме від наявності інвестицій, їх адекватності потребі розвитку та ефективності використання, зазначає О.І. Мельник, залежать економічний розвиток підприємств харчової промисловості та продуктивність аграрного сектору економіки України у цілому [8].

Підтвердженням ефективності концентрації капіталу, модернізації та оновлення виробництва, прогресивного менеджменту є діяльність кондитерської корпорації ROSHEN, яка у рейтингу Candy Industry Top 100 входить у першу двадцятку. Як зазначає у своїй статті О.В. Немировська [9], під власним «солодким знаком якості» ROSHEN виробляє понад 320 видів високоякісних кондитерських виробів (шоколадні і желейні цукерки, карамель, шоколад, печиво, вафлі, бісквітні рулети і торти). Загальний обсяг виробництва продукції сягає 450 тис т на рік. Головний офіс корпорації розташований у м. Києві. До складу корпорації входять українські фабрики (Київська, дві виробничі площадки у Вінниці та Кременчуцька); дві виробничі площадки Липецької кондитерської фабрики (Росія) (20 січня 2017 р. компанія «Рошен» остаточно зупинила роботу фабрики та оголосила про ліквідацію цього структурного підрозділу), Клайпедська кондитерська фабрика (Литва), Bonbonetti ChocoKft (Будапешт, Угорщина), а також масло-молочний комбінат «Бершадь молоко», який забезпечує фабрики корпорації натуральною високоякісною молочною сировиною. Для поліпшення умов зберігання сировини та готової продукції, для оптимізації поставок продукції та мінімізації затримок продукції на складі корпорація ввела в експлуатацію власні логістичні центри. Виробничі об'єкти кондитерської корпорації ROSHEN сертифіковані відповідно до вимог міжнародних стандартів якості та безпеки продуктів харчування. На підприємствах корпорації ROSHEN працює система управління якістю, яка відповідає вимогам ISO 9001: 2008, та система управління безпечністю харчових продуктів, яка відповідає вимогам стандарту ISO 22000:2005, що під- тверджується наявністю у кожної з фабрик корпорації сертифікатів відповідності. Усі кондитерські фабрики корпорації ROSHEN забезпечені обладнанням для моніторингу контролю якості продукції та відповідних досліджень. Розробленням технологій та запуском високоякісних кондитерських виробів займаються спеціалісти, які пройшли атестацію та навчання у спеціалізованих іноземних центрах. Представлені на ринку кондитерські вироби виготовлені за найсучаснішими технологіями. Експлуатація сучасного високовиробничого обладнання, чітке дотримання технології виробництва, використання виключно високоякісної сировини та матеріалів, що застосовуються під час виробництва кондитерських виробів, є запорукою головних переваг продукції ROSHEN.

Передумовою здійснення зазначених вище управлінських кроків $\epsilon$, на нашу думку, визначення взаємозв'язку продуктивності праці і капітальних інвестицій на одного зайнятого на підприємствах харчової промисловості України економетричними методами, які сьогодні є потужним інструментом для будь-якого дослідження. А моделювання економічних процесів за допомогою економетричних методів дає змогу виявити взаємозв'язки цих процесів та обгрунтувати їх сутність. Забезпечення економічного зростання галузі $\epsilon$ одним із головних питань соціально-економічного розвитку харчової промисловості. Як правило, у цьому разі спостерігається так звана «статистична залежність, коли зі зміною однієї випадкової величини змінюється закон розподілу ймовірностей іншої. Зокрема, статистична залежність виявляється у тому, що зі змінюванням однієї величини змінюється середнє значення іншої» [7].

У харчовій промисловості майже неможливо врахувати всі чинники, що впливають на результативність роботи галузі, тому доцільно розглянути найвизначніші 3 них.

Для цього побудовано однофакторні регресійні моделі, що складені на основі часових рядів продуктивності праці та питомих капітальних інвестицій.

Джерелом аналізу стали дані Державної служби статистики України. Як залежна змінна був вибраний рівень продуктивності праці, як незалежна - рівень питомих інвестицій.

У роботі проаналізовано період із 2012 по 2016 р. у силу наданих даних Державною службою статистики.

Як оцінка параметрів регресійних моделей застосований кореляційний аналіз результативності інноваційно-інвестиційного потенціалу 3 використанням низки показників, що характеризують якість моделі, ступінь відхилення від фактичних даних, а також значимість змінних. До них відносяться розрахунок коефіцієнта детермінації й обчислення середньої помилки апроксимації.

Для оцінки тісноти взаємозв'язку параметрів аналізованих моделей і виявлення напряму залежності елементів, а також якості побудованих моделей застосовувався коефіцієнт детермінації, значення якого показує, яка частина залежної змінної зумовлена варіацією залежної змінної.

Точність моделі характеризується близькістю розрахункових значень до фактичних спостережень на період апроксимацій. Уважається, що моделі з меншим розходженням між фактичними і розрахунковими значеннями краще відображають досліджуваний процес. 
Для характеристики ступеня близькості використовуються такі описові статистики: середнє квадратичне відхилення (або дисперсія), коефіцієнт детермінації (чим ближче до 1, тим точніша модель), середня відносна помилка апроксимації (чим ближче до 0, тим точніша модель), максимальне відхилення тощо.

Середня відносна помилка апроксимації розраховується за формулою:

$$
\bar{A}=\frac{1}{n} \sum\left|\frac{y-y^{*}}{y}\right| \cdot 100 \% .
$$

Думки вчених із приводу порогового значення середньої помилки апроксимації розходяться. Деякі вважають, що оптимальним є значення менше 10\%, інші акцентують увагу на порозі в $15 \%$. Автори схиляються до першої оцінки в силу більш точного дослідження. Окрім питомих інвестицій на продуктивність праці може впливати і низка інших чинників.

Після проведення процедури оцінки результуючим критерієм виступає коефіцієнт еластичності:

$$
\bar{E}=f^{\prime}(x) \frac{\bar{x}}{\bar{y}} .
$$

Середній коефіцієнт еластичності показує відносну зміну продуктивності праці під впливом одиничної відносної зміни питомих інвестицій за незмінності всіх інших факторів.

Результати кореляційно-регресійного аналізу продуктивності праці та капітальних інвестицій на одного зайнятого в харчовій промисловості України показують, що середня похибка апроксимації більше 15\%. Таким чином, отримані рівняння не можуть бути використані як регресія.

У рівняннях вільний член дуже високий, що свідчіть про неспівставність абсолютних значень обсягів реалізації продукції з розміром капітальних вкладень, які в низці галузей харчової промисловості незначні.

Це дає змогу сформулювати висновок про те, що пояснити зміну продуктивності праці на основі динаміки капітальних інвестицій на одного зайнятого не уявляється можливим: вплив інвестицій на продуктивність праці має більш складний механізм впливу.
Найважливішими факторами, від яких залежить рівень продуктивності праці, є техніко-технологічні чинники. Техніко-технологічні чинники пов'язані 3 використанням прогресивної технології, нової техніки, нових видів сировини і матеріалів. Упровадження у виробництво досягнень науково-технічного прогресу сприяє не тільки зниженню трудомісткості виробництва продукції, а й дає змогу скоротити витрати на сировину, матеріали, енергію та обладнання.

За результатами аналізу можна зробити висновок, що зростання продуктивності праці не забезпечується тільки за рахунок єдиного чинника виробництва - капіталу. Отже, необхідно використовувати такий показник, який поєднував би в собі два фактори виробництва: працю і капітал. Міру оснащеності праці основним капіталом характеризує показник фондоозброєності.

Для підвищення ефективності виробництва важливо, щоб було забезпечене випереджаюче зростання виробництва продукції порівняно з ростом основних засобів або випереджаюче зростання продуктивності праці порівняно з ростом іiі фондоозброєності [2].

У цьому разі досягається максимальна ефективність виробництва (фондовіддача зростає, й індекс фондовіддачі більше 100\%) (рис. 1).

У харчовій промисловості з 2015 р. простежується значне зниження продуктивності праці з 137,52\% до $107,43 \%$. Темпи приросту фондоозброєності праці з 2016 р. також мали тенденцію до зниження: 3 $127,34 \%$ до 78,79\%. При цьому протягом 2017-2018 pр. досягається випереджаюче зростання продуктивності праці порівняно з ростом іiі фондоозброєності, що свідчить про ефективність виробництва в харчовій промисловості.

Уважається, що зростання фондоозброєності - один iз важливих чинників підвищення ефективності суспільного виробництва. На основі впровадження інноваційно-інвестиційних заходів фондоозброєність будьякої галузі повинна постійно зростати.

Передумовою зростання продуктивності праці $\epsilon$, передусім, науково-технічний прогрес, упровадження ресурсозберігаючих технологій, удосконалення тех-

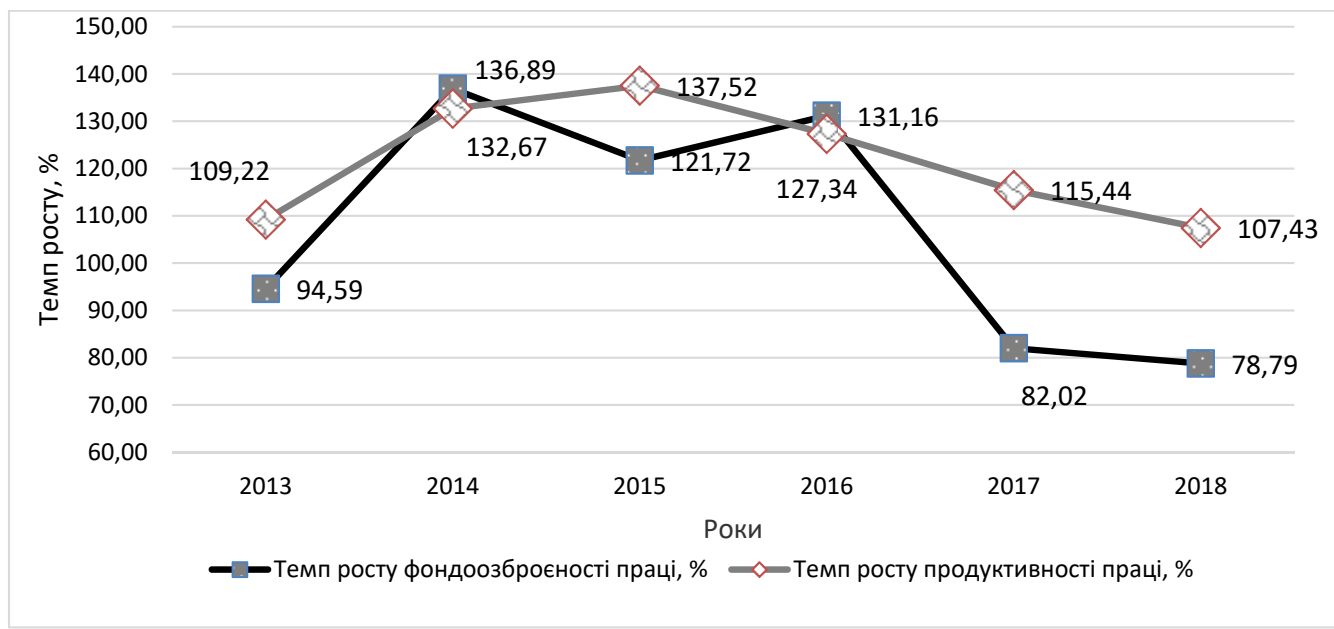

Рис. 1. Темпи росту фондоозброєності та продуктивності праці в харчовій промисловості України, \% 
нології виробництва і продукції. Витрати розвинених країн на науку і високі технології у десятки разів перевищують аналогічні витрати в Україні, що дає змогу розвивати виробництво високотехнологічної продукції, що приносить левову частку доходів від експорту, нарощувати обсяги виробництва конкурентоспроможних товарів і послуг [14].

Оцінку взаємозв'язку продуктивності праці та капітальних інвестицій на одного зайнятого й фондоозброєності праці в харчовій промисловості України представлено в табл. 5.

Коефіцієнти детермінації для кожного 3 рівнянь показують, на скільки відсотків варіація залежної продуктивності праці визначається варіацією пояснювальних змінних (капітальних інвестицій на одного зайнятого та фондоозброєності праці).

Так, у виробництві продуктів харчування та напоїв варіація продуктивності праці на 99,27\% залежить від капітальних інвестицій на одного зайнятого та фондоозброєності праці. Під час перероблення та консервування риби, ракоподібних і молюсків коефіцієнт детермінації має найменше значення - 79,44\%, тобто продуктивність праці на 79,44\% залежить від капітальних інвестицій на одного зайнятого та фондоозброєності праці а решта 20,56\% припадає на інші фактори та випадкові величини.

Ступінь тісноти зв'язку факторів моделі виражає множинний коефіцієнт кореляції.
Залежно від величини даного коефіцієнта, можна зробити висновок щодо важливості коливань у частині загальної кореляції під впливом чинників $x_{1}, x_{2}, \ldots, x_{n}$

Коефіцієнт кореляції (кореляційне відношення) $€$ відносною мірою зв'язку між ознаками, тому він може набувати значення від -1 до +1 . Чим ближче значення $r$ до \pm 1 , тим щільніший зв'язок. Знак + указує на прямий, а знак - - на зворотний зв'язок. За $r=0$ зв'язок відсутній.

Отримані значення коефіцієнта кореляції по галузях харчової промисловості свідчать про тісний кореляційний зв'язок між продуктивністю праці та капітальними інвестиціями на одного зайнятого й фондоозброєністю праці.

Отримані значення середньої похибки апроксимації свідчать про те, що моделі є адекватними $(<15,0 \%)$.

Найбільший вплив на зміну продуктивності праці спричиняе зміна капітальних інвестицій на одного зайнятого у виробництві інших продуктів харчування. Зростання капітальних інвестицій на одного зайнятого у виробництві інших продуктів харчування на 1\% дало змогу збільшити продуктивність праці в галузі в 1,471 рази.

Найбільший вплив на зміну продуктивності праці спричиняє зміна фондоозброєності праці під час виробництва олії та тваринних жирів. Так, зростання фондоозброєності праці на 1\% дало змогу збільшити продуктивність праці в галузі в 2,138 рази.

Економетрична оцінка взаємозв'язку продуктивності праці та капітальних інвестицій на одного зайнятого й фондоозброєності праці в харчовій промисловості України

\begin{tabular}{|c|c|c|c|c|c|c|}
\hline \multirow[b]{2}{*}{ Галузі промисловості } & \multirow[b]{2}{*}{ Рівняння регресії } & \multirow[b]{2}{*}{$\begin{array}{l}\text { Коефі- } \\
\text { ціснт } \\
\text { детермі- } \\
\text { нації, } R^{2}\end{array}$} & \multirow[b]{2}{*}{$\begin{array}{l}\text { Коефі- } \\
\text { ціснт } \\
\text { коре- } \\
\text { ляції, } r\end{array}$} & \multirow[b]{2}{*}{$\begin{array}{c}\text { Середня } \\
\text { похибка } \\
\text { апрок- } \\
\text { симації, } \\
\quad \%\end{array}$} & \multicolumn{2}{|c|}{ Коефіціснт еластичності } \\
\hline & & & & & $\begin{array}{c}\mathbf{X 1} \\
\text { (капітальні } \\
\text { інвестиції } \\
\text { на одного } \\
\text { зайнятого) } \\
\end{array}$ & $\begin{array}{c}\text { Х2 } \\
\text { (фондо- } \\
\text { озбро- } \\
\text { сність } \\
\text { праці) } \\
\end{array}$ \\
\hline Переробна промисловість & $\mathrm{Y}=9,70 \mathrm{X} 1+0,33 \mathrm{X} 2+154,64$ & 0,9995 & 0,9997 & 1,08 & 0,419 & 0,361 \\
\hline $\begin{array}{l}\text { Виробництво продуктів } \\
\text { харчування, напоїв }\end{array}$ & $Y=-6,68 X 1+3,57 X 2-141,13$ & 0,9927 & 0,9963 & 4,19 & $-0,292$ & 1,440 \\
\hline $\begin{array}{l}\text { Виробництво м`яса та } \\
\text { м'ясних продуктів }\end{array}$ & $Y=2,68 X 1+1,59 X 2+203,70$ & 0,8361 & 0,9144 & 11,33 & 0,103 & 0,603 \\
\hline $\begin{array}{l}\text { Перероблення та консерву- } \\
\text { вання риби, ракоподібних } \\
\text { і молюсків }\end{array}$ & $Y=67,24 X 1-1,89 X 2+332,89$ & 0,7944 & 0,8913 & 14,06 & 0,875 & $-0,391$ \\
\hline $\begin{array}{l}\text { Перероблення та консерву- } \\
\text { вання фруктів і овочів }\end{array}$ & $\mathrm{Y}=7,45 \mathrm{X} 1+1,29 \mathrm{X} 2+131,95$ & 0,9942 & 0,9971 & 2,76 & 0,273 & 0,579 \\
\hline $\begin{array}{l}\text { Виробництво олії } \\
\text { та тваринних жирів }\end{array}$ & $Y=0,99 X 1+9,16 X 2-4443,64$ & 0,9769 & 0,9884 & 8,76 & 0,03 & 2,138 \\
\hline $\begin{array}{l}\text { Виробництво молочних } \\
\text { продуктів }\end{array}$ & $Y=13,32 X 1+1,94 X 2-90,06$ & 0,9999 & 0,9999 & 0,15 & 0,469 & 0,659 \\
\hline $\begin{array}{l}\text { Виробництво продуктів } \\
\text { борошномельно-круп`яної } \\
\text { промисловості, крохмалів та } \\
\text { крохмальних продуктів }\end{array}$ & $\mathrm{Y}=6,5 \mathrm{X} 1+5,88 \mathrm{X} 2-857,32$ & 0,9654 & 0,9825 & 10,25 & 0,26 & 1,681 \\
\hline $\begin{array}{l}\text { Виробництво хліба, хлібобу- } \\
\text { лочних і борошняних виробів }\end{array}$ & $Y=5,51 X 1+0,56 X 2+106,63$ & 0,9949 & 0,9974 & 2,53 & 0,172 & 0,478 \\
\hline \begin{tabular}{|l|} 
Виробництво інших \\
харчових продуктів
\end{tabular} & $Y=17,48 X 1+0,42 X 2-676,67$ & 0,8946 & 0,9458 & 11,22 & 1,471 & 0,23 \\
\hline $\begin{array}{l}\text { Виробництво готових кормів } \\
\text { для тварин }\end{array}$ & $\mathrm{Y}=1,27 \mathrm{X} 1+3,73 \mathrm{X} 2+33,82$ & 0,9989 & 0,9994 & 1,95 & 0,028 & 0,95 \\
\hline Виробництво напоїв & $\mathrm{Y}=10,19 \mathrm{X} 1+1,42 \mathrm{X} 2-401,29$ & 0,9845 & 0,9922 & 3,93 & 0,471 & 0,845 \\
\hline
\end{tabular}

Джерело: розраховано з використанням [4] 
Висновки 3 проведеного дослідження. У результаті проведеного дослідження інноваційно-інвестиційного потенціалу результативності встановлено, що інвестиції впливають на продуктивність праці опосередковано, тобто через додатковий механізм, у функціонуванні якого можна виділити кілька ступенів (ланок): перша ланка передбачає збільшення інвестицій в основні засоби; на другій ланці за рахунок зростання вартості основних засобів відбувається зростання фондоозброєності праці, яка на третій ланці призводить до збільшення валової доданої вартості, що веде до зростання продуктивності праці.

Економетрична оцінка результативності інноваційно-інвестиційного потенціалу дала змогу встановити залежність капітальних інвестицій на одного зайнятого та фондоозброєності праці на продуктивність праці в харчовій промисловості, яка має високий рівень коефіцієнта детермінації $(0,9928)$, що свідчить про залежність продуктивності праці від досліджуваних факторів на 99,28\%. Саме тому ключовим напрямом підвищення ефективності харчової промисловості $€$ збільшення інвестицій у галузі, у тому числі й іноземних, та зростання рівня фондоозброєності.

За результатами оцінки значень коефіцієнта еластичності можна стверджувати, що збільшення капітальних інвестицій на одного зайнятого в переробній галузі України на 1\% здатне підвищити продуктивність праці в середньому на $0,419 \%$. При цьому слід урахо- вувати, що зростання фондоозброєності праці у виробництві продуктів харчування та напоїв на 1\% збільшує продуктивність праці в галузі у 1,44 рази.

Слід акцентувати увагу на тому, що вплив досліджуваних чинників на продуктивність праці як один з основних показників використання персоналу та ефективності використання інноваційно-інвестиційного потенціалу галузі у цілому є значним, що підтверджується отриманими стохастичними даними лінійних регресій.

Для вирішення завдання щодо зростання продуктивності праці до рівня розвинених країн виникає нагальна потреба проведення перспективних заходів в напрямі підвищення інвестицій в основний капітал харчової промисловості з метою модернізації виробничого обладнання, зниження частки застарілого та підвищення частки високотехнологічного обладнання. Цьому сприятиме поліпшення ділового та інвестиційного клімату за рахунок більш активної участі провідних світових транснаціональних корпорацій на внутрішньому ринку України, оскільки вони вкладають більше капіталу на одиницю праці, що має безпосередній зв'язок із підвищенням рівня фондоозброєності. Це сприятиме більшій віддачі інноваційно-інвестиційного потенціалу харчової промисловості, зростанню продуктивності праці, що так потрібно для впровадження політики модернізації харчової промисловості України й поступового, а краще інтенсивного її відходу від експортно-сировинної моделі.

1. База даних «Руслана». URL: https://ruslana.bvdep.com.

2. Бондаревська К.В. Економіко-математичне моделювання залежності продуктивності праці від основних факторів. Вісник Дніпропетровської державної фінансової академії. 2011. № 2. C. 148-153. URL: http://biblio.umsf.dp.ua/ jspui/handle/123456789/1556.

3. Гуткевич С.О. Інвестування: теорія і практика : навчальний посібник. Київ : Європ. ун-т, 2006.233 с.

4. Державна служба статистики України. Статистична інформація. URL: http://www.ukrstat.gov.ua.

5. Заюков I.В. Продуктивність праці в контексті забезпечення інноваційного розвитку економіки України. Економіка: реалї̈ часу. 2015. № 2 (18). С. 236-242.

6. Колот А.М., Герасименко О.О. Гідна праця як концепція та стратегічний напрям розвитку соціально-трудової сфери. Україна: аспекти праціi. 2015. № 6. С. 3-13.

7. Лещинський О.Л., Рязанцева В.В., Юнькова О.О. Економетрія : навчальний посібник. Київ : Персонал, 2008. 208 c. URL: http://maup.com.ua/assets/files/lib/book/dmo_5.pdf.

8. Мельник О.І., Мельник А.Г., Пасічник Ю.А. Організаційно-економічні умови активізації інвестиційної діяльності в аграрному секторі економіки України. Агросвіт. 2018. № 22. С. 3-9.

9. Немировська О.В. Аналіз та оцінка економічної діяльності ТНК в Україні. Ефективна економіка. 2014. № 12. URL: http://www.economy.nayka.com.ua/?op=1\&z=3643.

10. Парамонова К.М., Федулова Л.І. Розробка програми підвищення продуктивності праці. Вісник КНУТД. 2012. № 6. C. 320-325.

11. Пєнська І.О. Особливості впливу ТНК на економічний розвиток України. Зовнішня торгівля: економіка, фінанси, право. Серія «Економічні науки». 2015. № 3(80).

12. Созаева Д.А. Инновационно-инвестиционный потенциал как характеристика состояния региональной инновационной системы. URL: https:/cyberleninka.ru/article/n/innovatsionno-investitsionnyy-potentsial-kakharakteristika-sostoyaniya-regionalnoy-innovatsionnoy-sistemy.

13. Чорна Р.М. Продуктивність праці у сільському господарстві як основний чинник, що визначає науково-технічний прогрес галузі. Продуктивність агропромислового виробництва. Економічні науки. 2013. Вип. 23. С. 126-133.

14. Шахно А.Ю, Короленко О.Б., Марендич Р.С. Проблеми та перспективи зростання продуктивності праці людського капіталу в умовах глобалізації. Економіка. Управління. Інновації. Серія «Економічні науки». 2016. № 4. URL: http://nbuv.gov.ua/UJRN/eui_2016_4_20.

\section{References:}

1. Baza danyx «Ruslana». URL: https://ruslana.bvdep.com (in Ukrainian)

2. Bondarevska K.V. (2011) Ekonomiko-matematychne modelyuvannya zalezhnosti produktyvnosti praci vid osnovnyx faktoriv [Mathematical and economic modeling of the labor productivity dependence on basic factors in 
agrarian business] Elektronne vydannya Visnyk Dnipropetrovskoyi derzhavnoyi finansovoyi akademiyi [Electronic edition Bulletin of the Dnipropetrovsk State Financial Academy], no. 2, pp. 148-153. Available at: http://biblio.umsf.dp.ua/jspui/ handle/123456789/1556). (in Ukrainian)

3. Gutkevych S.O. (2006) Investuvannia: teoriia i praktyka [Investing: theory and practice] navch. posib. dlia stud. vyshch. navch. zakl. Yevrop. un-t. Kyiv, 233 p. (in Ukrainian)

4. Derzhavna sluzhba statystyky Ukrajiny. Statystychna informacija. URL: http://www.ukrstat.gov.ua. (in Ukrainian)

5. Zaiukov I.V. (2015) Produktyvnist pratsi v konteksti zabezpechennia innovatsiinoho rozvytku ekonomiky Ukrainy [Labor productivity in the context of ensuring the innovative development of Ukraine's economy]. Ekonomika: realii chasu [Economy: the realities of time], no. 2 (18), pp. 236-242. (in Ukrainian)

6. Kolot A.M., Herasymenko O.O. (2015) Hidna pratsia yak kontseptsiia ta stratehichnyi napriam rozvytku sotsialnotrudovoi sfery [Decent work as a concept and strategic direction of development of the social and labor sphere]. Ukraina: aspekty pratsi [Ukraine: aspects of work], no. 6, pp. 3-13. (in Ukrainian)

7. Leshchynskyi O.L., Riazantseva V.V., Yunkova O.O. (2008) Ekonometriia [Econometrics]: navch. posibnyk. Kyiv: DP «Vyd. dim «Personal», 208 p. Available at: http://maup.com.ua/assets/files/lib/book/dmo_5.pdf. (in Ukrainian)

8. Melnyk O.I., Melnyk A.H., Pasichnyk Yu.A. (2018) Orhanizatsiino-ekonomichni umovy aktyvizatsii investytsiinoi diialnosti v ahrarnomu sektori ekonomiky Ukrainy [Organizational and economic conditions for intensifying investment activity in the agricultural sector of Ukraine's economy]. Ahrosvit [Agrosvit], no. 22, pp. 3-9. (in Ukrainian)

9. Nemyrovska O.V. (2014) Analiz ta otsinka ekonomichnoi diialnosti TNK v Ukraini [Analysis and evaluation of economic activity of TNCs in Ukraine]. Efektyvna ekonomika [Efficient economy]. № 12. Available at: http://www.economy.nayka.com.ua/?op=1\&z=3643. (in Ukrainian)

10. Paramonova K.M., Fedulova L.I. (2012) Rozrobka prohramy pidvyshchennia produktyvnosti pratsi [Development of a program to increase productivity.]. Visnyk KNUTD [Bulletin of KNUTD], no. 6, pp. 320-325. (in Ukrainian)

11. Pienska I.O. (2015) Osoblyvosti vplyvu TNK na ekonomichnyi rozvytok Ukrainy [Features of the influence of TNCs on the economic development of Ukraine]. Zovnishnia torhivlia: ekonomika, finansy, pravo [Foreign trade: economics, finance, law]. Naukovyi zhurnal. Seriia: Ekonomichni nauky, no. 3 (80). (in Ukrainian)

12. Sozaeva D.A. Innovatsionno-investitsionnyiy potentsial kak harakteristika sostoyaniya regionalnoy innovatsionnoy sistemyi [Innovation and investment potential as a characteristic of the state of the regional innovation system]. Available at: https://cyberleninka.ru/article/n/innovatsionno-investitsionnyy-potentsial-kak-harakteristika-sostoyaniya-regionalnoyinnovatsionnoy-sistemy (in Russian)

13. Chorna R.M. (2013) Produktyvnist pratsi u silskomu hospodarstvi yak osnovnyi chynnyk, shcho vyznachaie naukovo-tekhnichnyi prohres haluzi [Labor productivity in agriculture as the main factor that determines the scientific and technological progress of the industry]. Produktyvnist ahropromyslovoho vyrobnytstva. Ekonomichni nauky [Productivity of agro-industrial production. Economic sciences], no. 23, pp. 126-133. (in Ukrainian)

14. Shakhno A.Iu, Korolenko O.B., Marendych R.S. (2016) Problemy ta perspektyvy zrostannia produktyvnosti pratsi liudskoho kapitalu v umovakh hlobalizatsii [Problems and prospects for increasing the productivity of human capital in the context of globalization]. Ekonomika. Upravlinnia. Innovatsii [Economy. Management. Innovations]. Seriia: Ekonomichni nauky. № 4. Available at: http://nbuv.gov.ua/UJRN/eui_2016_4_20. (in Ukrainian)

E-mail:busiv@ukr.net

E-mail:n.s.kotkova@gmail.com 